\title{
Pidoplitchkoviella terricola - an interesting fungus from the Domica Cave (Slovakia)
}

\author{
Alena Nováková ${ }^{1}$
}

\begin{abstract}
:
Nováková A. 2009. Pidoplitchkoviella terricola - an interesting fungus from the Domica Cave (Slovakia). International Journal of Speleology, 38 (1), 23-26. Bologna (Italy). ISSN 0392-6672.

The microfungus Pidoplitchkoviella terricola - until now it was known only as Kirilenko's specimen isolated from Quercus robur rhizosphere in Ukraine - was found in earthworm casts in the Domica Cave, NP Slovak Karst, Slovakia. A description and microphotographs of this strain are provided in this article.
\end{abstract}

Keywords: Domica Cave, earthworm casts, Pidoplitchkoviella terricola

Received 29 April 2008; Revised 12 June 2008; Accepted 10 July 2008

\section{INTRODUCTION}

Considering the constant temperature and humidity, absence of light, and mostly the absence or limited amount of organic material in caves, caves are a very appropriate environment for living organisms. The microfungal community in caves is very specific, and caves can frequently be a source of very interesting species including relicts of fossilized microfungal spores (Rutherford \& Huang, 1994). Long-term viable microfungal spores can be found in various cave substrates, such as cave air and sediments, but also in substrates accumulated by bats and other mammals visiting caves (marten, dormouse, etc.) or created by cave dwelling invertebrates (earthworm casts, arthropods faeces). The aim of our study was to estimate microfungal diversity in various cave substrates in several caves of the Slovak Karst National Park (Nováková, 2004, 2005).

Pidoplitchkoviella terricola (Ascomycetes, Xylariales) was isolated by Kirilenko from the rhizosphere of Quercus robur in Ukraine (CBS Fungi database) and until now it was known only from this one isolate. In 2002 this microfungal species was isolated by us from earthworm casts in the Domica Cave.

\section{MATERIAL AND METHODS}

A sample was collected from earthworm casts situated on speleothems (Fig. 1) in an adjoining corridor near the Japanese Teahouse in the Domica Cave (Slovak Karst National Park, Slovakia) on 24 April 2002.

The soil dilution method and three isolation media (Martin's agar with soil extract, Sabouraud's and beer

1 Biology Centre, AS CR, v.v.i., Institute of Soil Biology, Na Sádkách 7, CZ-370 05 České Budějovice, Czech Republic, E-mail address: alena@upb.cas.cz

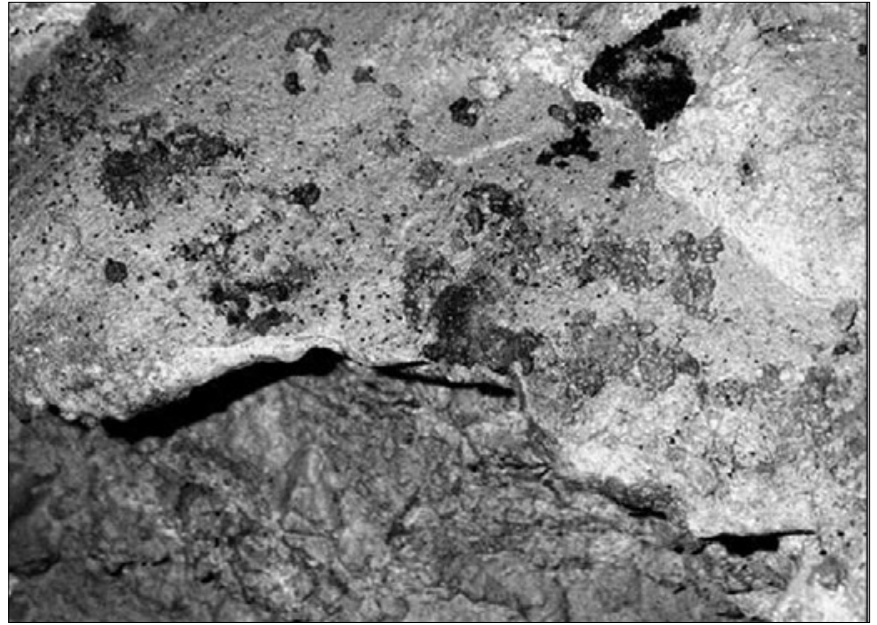

Fig. 1. A view on earthworm casts on the speleotheme, adjoining corridor near the Japanese Teahouse in the Domica Cave.

wort agars) with rose bengal, chloramphenicol and streptomycin were used for the isolation of microfungi (Garrett, 1981; Kreisel \& Schauer, 1987). Three Petri dishes for each isolation medium were incubated in the dark at $25{ }^{\circ} \mathrm{C}$ for 7 days. Determination of isolated microfungi was carried out on malt extract agar (MEA), potato dextrose agar (PDA) and carrot agar (CA) (Kreisel \& Schauer, 1987). A fungus that showed dark pigmented ascomata production on CA was identified as Pidoplitchkoviella terricola Kiril. following the criteria of predominantly non-ostiolate, dark brown ascomata and triangular ascospores.

Small agar blocks removed from ten days colonies on PDA and MEA were fixed in a $2.5 \%$ glutaraldehyde solution and a $0.2 \mathrm{M}$ phosphate buffer followed by fixation in a $2 \% \quad \mathrm{OsO}_{4}$ solution, dehydrated in a graded series of acetone solutions and by the critical point drying method (Kučerová - pers. comm.). 
Observations were done on a JEOL 6300 scanning electron microscope.

\section{DESCRIPTION OF THE ISOLATED STRAIN OF PIDOPLITCHKOVIELLA TERRICOLA KIRIL.}

Colonies growing on CA attained $1.0-1.2 \mathrm{~cm}$ in diameter, and were sulcate, brown-black with dark pigmented reverse (Fig. 2A); colonies on PDA attained $0.5-0.6 \mathrm{~cm}$ in diameter, and were sulcate with radial wrinkles at the margins, natural white with a greyish to black centre, a yellowish pigmented reverse, and a light yellow pigment diffusing to the medium was observed; colonies on MEA attained $2-2.2 \mathrm{~cm}$ in diameter, white to cream, wrinkled, after 12-14 days with visible darker pigmented areas due to the production of ascomata; reverse beige to light ochre (Fig. 2B).

Ascomata superficial, spherical, without ascomatal hairs, predominantly non-ostiolate, ostiolate in some cases (Fig. 3A, B, 4A), dark brown, 50-120 $\mathrm{m}$ in diameter, ascomatal wall pale, with textura epidermoidea, asci cylindric-clavate, fasciculate, thinwalled, 8-spored, evanescent, 28-36 x 7-9 $\mu \mathrm{m}$ (Fig. $3 \mathrm{C}$ ); ascospores 1-celled, aseptate, triangular in lateral view, pale brown, 7-9 x 2,8-3,5 $\mu \mathrm{m}$, without germ pores (Fig. 3D, 4B). No anamorph was observed.

Examined material: strain CMF 1376 (Collection of Microscopic Fungi ISB)(Nováková, 2007), earthworm casts, the Domica Cave, Slovak Karst National Park, Slovakia, coll. A. Nováková, 24 April 2002.

\section{DISCUSSION}

Unfortunately only one strain of $P$. terricola could be studied in the present study, although several samples of earthworm casts and also samples of cave sediments from various sites of the Domica Cave were collected in the same time and repeatedly in the following years, this fungus did not succeed in being isolated again. Morphological features of our isolate corresponded with Kirilenko's original diagnosis (predominantly created non-ostiolate, but occasionally ostiolate ascomata). However, false statements about $P$. terricola resulting probably from incorrect translations of original paper were published in former times, e.g., only non-ostiolate ascomata (von Arx et al., 1986) and the isolation from the rhizosphere of Quercus rubra (Suh \& Blackwell, 1999). This fungus also has some similarities with some species of the family Chaetomiaceae (Ascomycetes, Sordariales) such as Chaetomidium triangulare Stchigel \& Guarro (Stchigel et al., 2004), Chaetomium trigonosporum (Marchal) Chivers and C. microascoides Guarro and with other ascomycete species with triangular ascospores, such as Microascus trigonosporus C. W. Emmons \& B. O. Dodge var. trigonosporus and $M$. trigonosporus var. macrosporus G. F. Orr. Chaetomidium triangulare has also non-ostiolate ascomata without hairs, but differs from $P$. terricola by having triangular ascospores with a visible germ pore and in the textura angularis of the peridial wall. Chaetomium microascoides has ostiolate and beaked ascomata with straight or reflexed hairs, but $C$. trigonosporum differs from $P$. terricola mainly by having seta-like hairs and Scopulariopsis anamorph (von Arx et al., 1986). The species of the genus Microascus differs by ostiolate ascocarps (Domsch et al., 2007), obovate to spherical asci, straw coloured to reddish brown ascospores, and by the presence of Scopulariopsis or Wardomyces anamorphs (von Arx et al., 1988; Stchigel et al., 2004).

Kirilenko's original diagnosis shows affinities of the genus Pidoplitchkoviella to the genera Microascus Zukal, Pithoascus Arx, (Microascaceae) Melanospora Corda (Ceratostomataceae), and Tripospora Sacc. (Coryneliaceae). On the contrary, von Arx et al. (1988) placed this genus as a member of the family Pithoascaceae (Sordariaceous Ascomycetes; Sphaeriales) together with the genera Pithoascus, Faurelina, and Leuconeurospora, whereas ascospores without germ pores are typical of this family. Currently Pidoplitchkoviella is included to the family Xylariaceae (Xylariales, Xylariomycetidae, Sordariomycetes) (Lumbsch \& Huhndorf, 2007). This family includes mainly stromatic ascomycetes with perithecial ascomata with hairs and dark brown pigmented ascospores (Hawksworth et al., 1996). Although $P$. terricola is non-stromatic species with

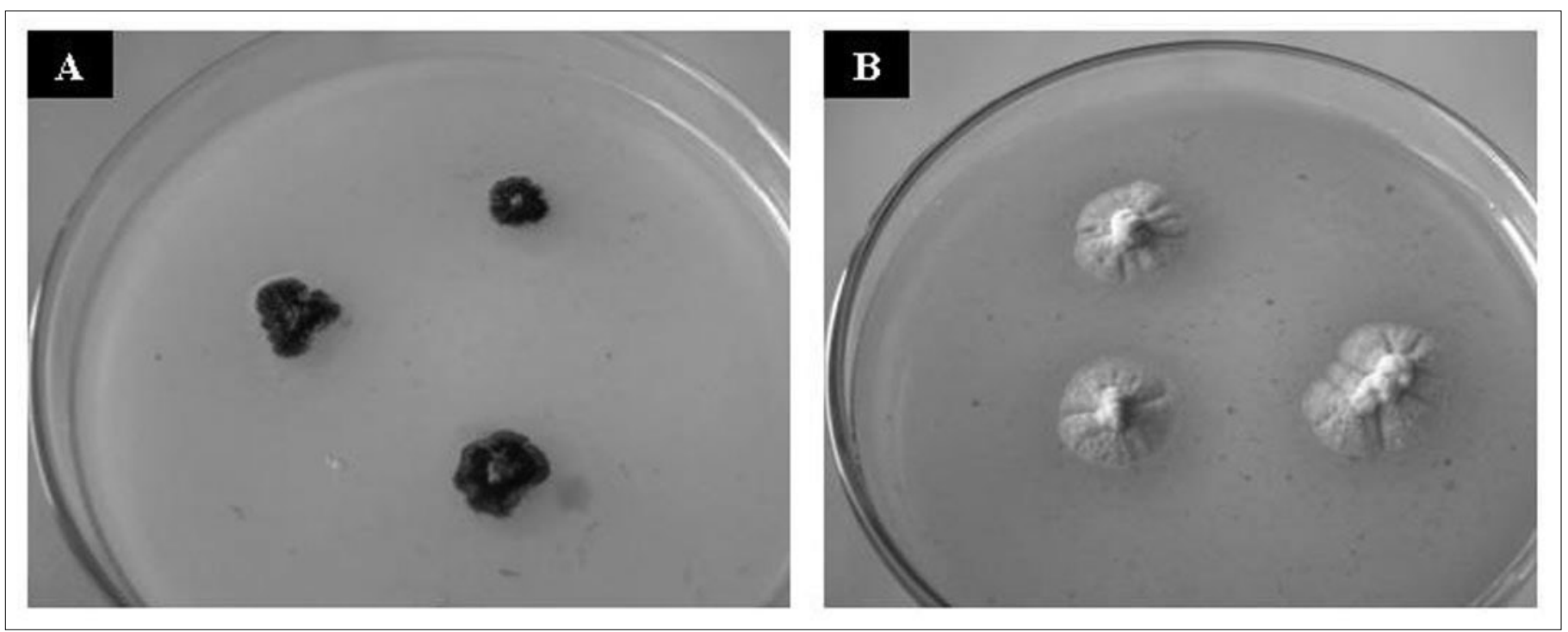

Fig. 2. Colonies of $P$. terricola on carrot $(A)$ and potato dextrose $(B)$ agars, 10 days at $25^{\circ} \mathrm{C}$. 

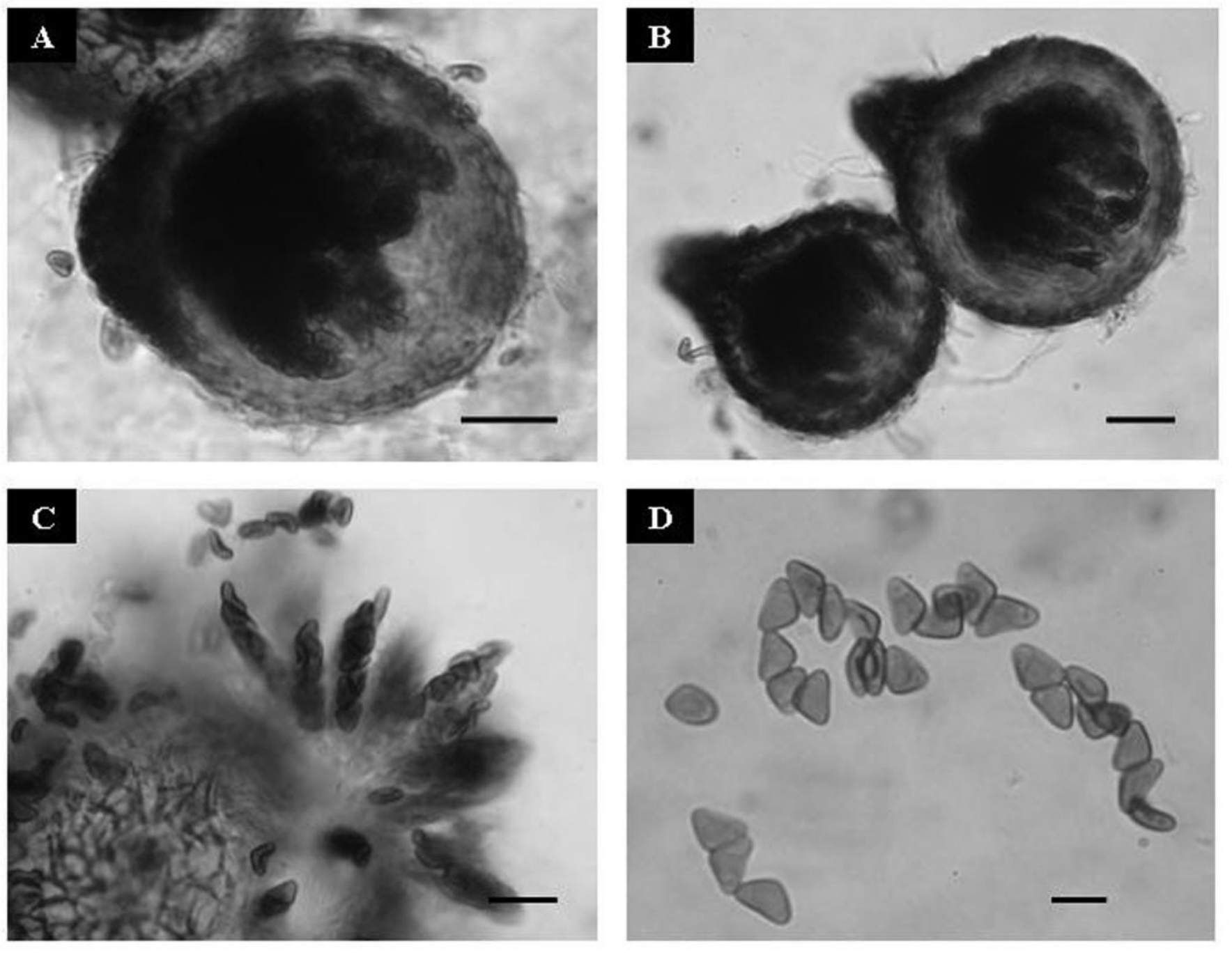

Fig. 3. A - Non-ostiolate ascocarp, B - ostiolate ascocarps, $\mathrm{C}$ - elongate asci with ascospores $\mathrm{D}-$ triangular ascospores $($ bar $=10 \mu \mathrm{m})$.
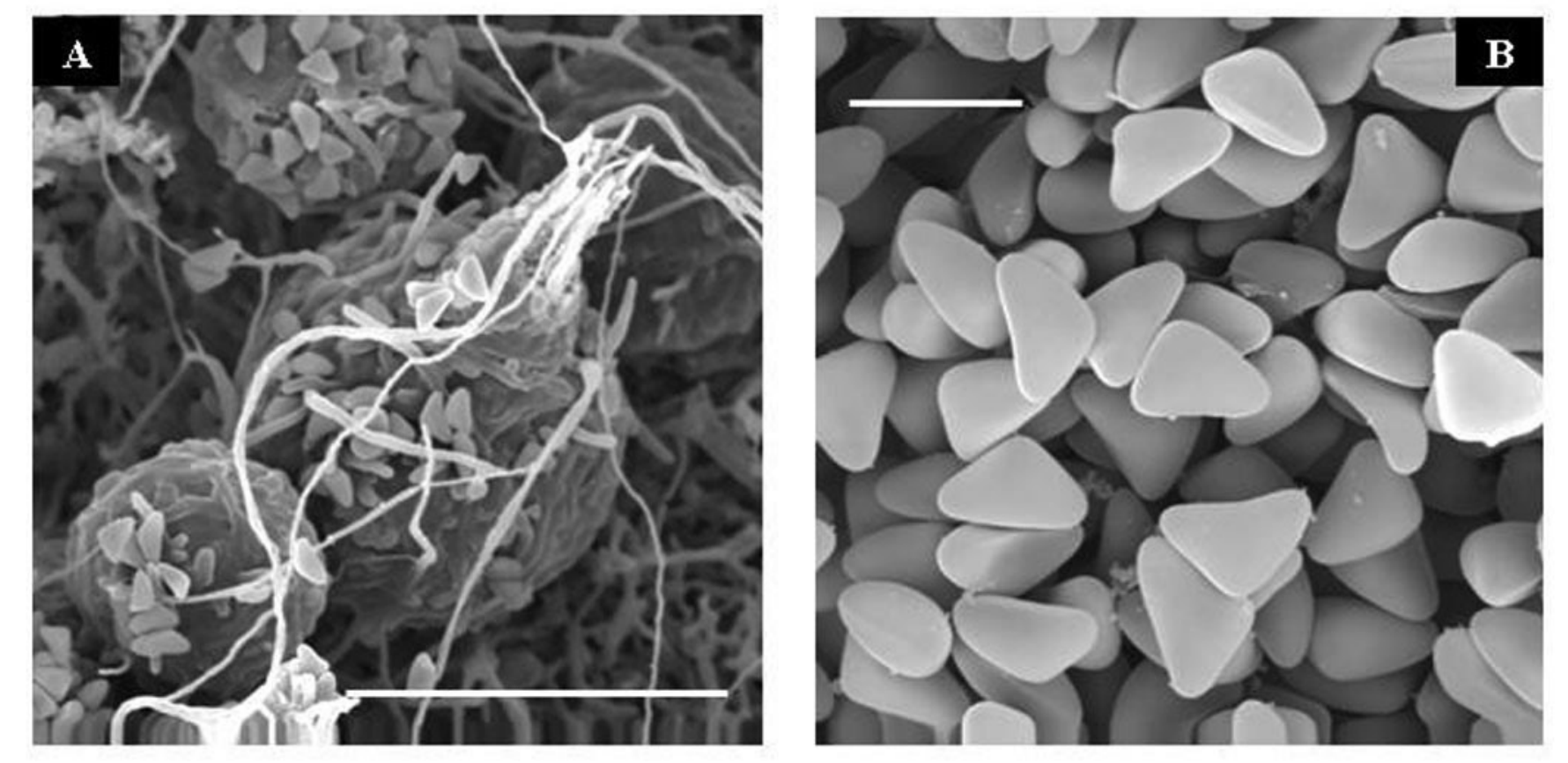

Fig. 4. SEM micrographs of $P$. terricola. $A$ - ascocarps $(b a r=50 \mu \mathrm{m}), B-$ triangular ascospores $(b a r=10 \mu m)$. 
light pigmented ascospores, and with predominantly globose or subglobose cleistothecial, non-ostiolate ascomata without hairs, considering the SSU rDNA analyses, $P$. terricola was placed finally in the clades of Xylariales (Suh \& Blackwell, 1999).

\section{ACKNOWLEDGEMENTS}

This work was supported by the Research Plan of the ISB BC AS CR, v.v.i. No. AV0Z60660521. The author is grateful to Martina Tesařová and Věra Kučerová, the Laboratory of Electron Microscopy of the Institute of Parasitology BC AS CR, v.v.i., for help with SEM analysis, to the Slovak Cave Administration for allowing entry to cave and to Lubomír Kováč, Andrej Mock and Peter Luptáčik for helping during sampling in caves.

\section{REFERENCES}

Domsch K.H., Gams W. \& Anderson T.-H., 2007 Compendium of Soil Fungi. 2nd Ed., IHW Verlag, Eching bei München, $672 \mathrm{p}$.

Garrett S.D. 1981 - Soil Fungi and Soil Fertility. Pergamon Press, Oxford

Hawksworth D.L., Kirk P.M., Sutton B.C. \& Pegler D.N., 1996 - Ainsworth and Bisby's Dictionary of the Fungi. 8th Ed., CAB International, Wallingford and New York, $616 \mathrm{p}$.

Kirilenko S.T., 1975 - Pidoplitchkoviella terricola - a new ascomycete. Mikrobiologicheskii Zhurnal, 37: 603-605. [in Ukrainian with English summary]

Lumbsch H.T. \& Huhndorf S.M., 2007 Outline in Ascomycota - 2007. Myconet, 13. http://www.fieldmuseum.org/myconet/outline.asp
Kreisel H. \& Schauer F., 1987 - Methoden Des Mykologischen Laboratoriums, Gustav Fischer Verlag, Stuttgart.

Nováková A., 2004 - Microscopic fungi in caves of the National Park Slovak Karst. Phytopedon, 3: 26-31.

Nováková A., 2005 - Interesting and rare saprotrophic microfungi isolated from excrements and other substrates in the Domica and Ardovská Caves. In: Tajovský K., Schlaghamerský J. \& Pižl V. (Eds.), Contributions to Soil Zoology in Central Europe I., České Budějovice: ISB AS CR: pp. 103-106.

Nováková A., 2007 - Collection of Microscopic Fungi - A Catalogue of Strains. ISB BC AS CR, v.v.i., České Budějovice, 55 p.

Rutherford J.M. \& Huang L.H., 1994 - A study of fungi of remote sediments in West Virginia caves and a comparison with reported species in the literature. NSS Bulletin, 56: 38-45.

Stchigel M.A., Guarro J., Jato V. \& Aira M.J., 2004 - Two new species of Chaetomidium (Sordariales). Studies in Mycology, 50: 215-220.

Suh S.-O. \& Blackwell M., 1999 - Molecular phylology of the cleistothecial fungi placed in Cephalothecaceae and Pseudeurotiaceae. Mycologia, 91: 836-848.

von Arx J.A., Guarro J. \& Figueras M.J., 1986 The Ascomycete Genus Chaetomium. J. Cramer, Berlin and Stuttgart, $162 \mathrm{p}$.

von Arx J. A., Figueras M.J. \& Guarro J., 1988 Sordariaceous Ascomycetes without Ascospore Ejaculation. J. Cramer, Berlin and Stuttgart, 104 p. 